University of Montana

ScholarWorks at University of Montana

\title{
Indirect Effects and Traditional Trophic Cascades: a Test Involving Wolves, Coyotes, and Pronghorn
}

\author{
Kim Murray Berger \\ Eric M. Gese \\ Joel Berger \\ University of Montana - Missoula, joel.berger@mso.umt.edu
}

Follow this and additional works at: https://scholarworks.umt.edu/biosci_pubs

Part of the Biology Commons

Let us know how access to this document benefits you.

\section{Recommended Citation}

Berger, Kim Murray; Gese, Eric M.; and Berger, Joel, "Indirect Effects and Traditional Trophic Cascades: a Test Involving Wolves, Coyotes, and Pronghorn" (2008). Biological Sciences Faculty Publications. 78. https://scholarworks.umt.edu/biosci_pubs/78

This Article is brought to you for free and open access by the Biological Sciences at ScholarWorks at University of Montana. It has been accepted for inclusion in Biological Sciences Faculty Publications by an authorized administrator of ScholarWorks at University of Montana. For more information, please contact scholarworks@mso.umt.edu. 


\title{
INDIRECT EFFECTS AND TRADITIONAL TROPHIC CASCADES: A TEST INVOLVING WOLVES, COYOTES, AND PRONGHORN
}

\author{
Kim Murray Berger, ${ }^{1,2,4}$ Eric M. Gese, ${ }^{3}$ and Joel Berger ${ }^{2}$ \\ ${ }^{1}$ Department of Wildland Resources, Utah State University, Logan, Utah 84322-5230 USA \\ ${ }^{2}$ Wildife Conservation Society, Northern Rockies Field Office, 205 Natural Science Building, University of Montana, \\ Missoula, Montana 59812 USA \\ ${ }^{3}$ United States Department of Agriculture, Wildife Services, National Wildlife Research Center, Department of Wildland Resources, \\ Utah State University, Logan, Utah 84322-5230 USA
}

\begin{abstract}
The traditional trophic cascades model is based on consumer-resource interactions at each link in a food chain. However, trophic-level interactions, such as mesocarnivore release resulting from intraguild predation, may also be important mediators of cascades. From September 2001 to August 2004, we used spatial and seasonal heterogeneity in wolf distribution and abundance in the southern Greater Yellowstone Ecosystem to evaluate whether mesopredator release of coyotes (Canis latrans), resulting from the extirpation of wolves (Canis lupus), accounts for high rates of coyote predation on pronghorn (Antilocapra americana) fawns observed in some areas. Results of this ecological perturbation in wolf densities, coyote densities, and pronghorn neonatal survival at wolf-free and wolf-abundant sites support the existence of a species-level trophic cascade. That wolves precipitated a trophic cascade was evidenced by fawn survival rates that were four-fold higher at sites used by wolves. A negative correlation between coyote and wolf densities supports the hypothesis that interspecific interactions between the two species facilitated the difference in fawn survival. Whereas densities of resident coyotes were similar between wolf-free and wolf-abundant sites, the abundance of transient coyotes was significantly lower in areas used by wolves. Thus, differential effects of wolves on solitary coyotes may be an important mechanism by which wolves limit coyote densities. Our results support the hypothesis that mesopredator release of coyotes contributes to high rates of coyote predation on pronghorn fawns, and demonstrate the importance of alternative food web pathways in structuring the dynamics of terrestrial systems.
\end{abstract}

Key words: Antilocapra americana; Canis latrans; Canis lupus; carnivore competition; mesopredator release hypothesis; predator-prey; Program MARK.

\section{INTRODUCTION}

Large carnivores can shape the structure and function of ecological communities (Ray et al. 2005), yet few ecosystems still harbor apex predators (Schaller 1996). Most species are declining globally due to habitat loss, fragmentation, disease, and human persecution (Weber and Rabinowitz 1996, Woodroffe and Ginsberg 1998, Woodroffe 2001), the latter often as a result of conflicts over livestock (Johnson et al. 2001, Ogada et al. 2003, Berger 2006). In addition to threatening the survival of these species, the loss of large carnivores carries broader implications for the maintenance of biodiversity as a result of indirect effects at lower trophic levels (Crooks and Soulé 1999, Henke and Bryant 1999). For instance, in the absence of grizzly bears (Ursus arctos) and wolves (Canis lupus) in the southern Greater Yellowstone

Manuscript received 5 February 2007; revised 19 June 2007; accepted 9 July 2007. Corresponding Editor: J. M. Fryxell.

4 Address for correspondence: Wildlife Conservation Society, Northern Rockies Field Office, 205 Natural Science Building, University of Montana, Missoula, Montana 59812 USA. E-mail: kberger@wcs.org
Ecosystem (GYE), moose (Alces alces) numbers expanded, resulting in a reduction in both willow communities and the attendant diversity of neotropical songbirds (Berger et al. 2001). Similarly, the extirpation of vertebrate predators led to a 10 - to 100 -fold increase in herbivore densities and a concomitant decrease in the number of seedlings and saplings of canopy trees on islands in Venezuela (Terborgh et al. 2001).

Trophic cascades have been defined as predationrelated effects that result in inverse patterns of abundance or biomass across multiple trophic levels in a food web (Micheli et al. 2001). Although the classic cascade is based on a three-tiered system consisting of predators, herbivores, and plants (Hairston et al. 1960), cascades can involve more than three trophic levels and apply to any multilink linear food web interaction (Polis et al. 2000). In systems with top-down control, the pattern of biomass that emerges depends on the number of trophic levels (Fig. 1). In even-numbered food chains with four or more trophic levels, herbivores can expand and overgraze plant communities because mesocarnivores are held in check by apex carnivores (Fig. 1; Oksanen et al. 1981, Fretwell 1987). The loss of primary 


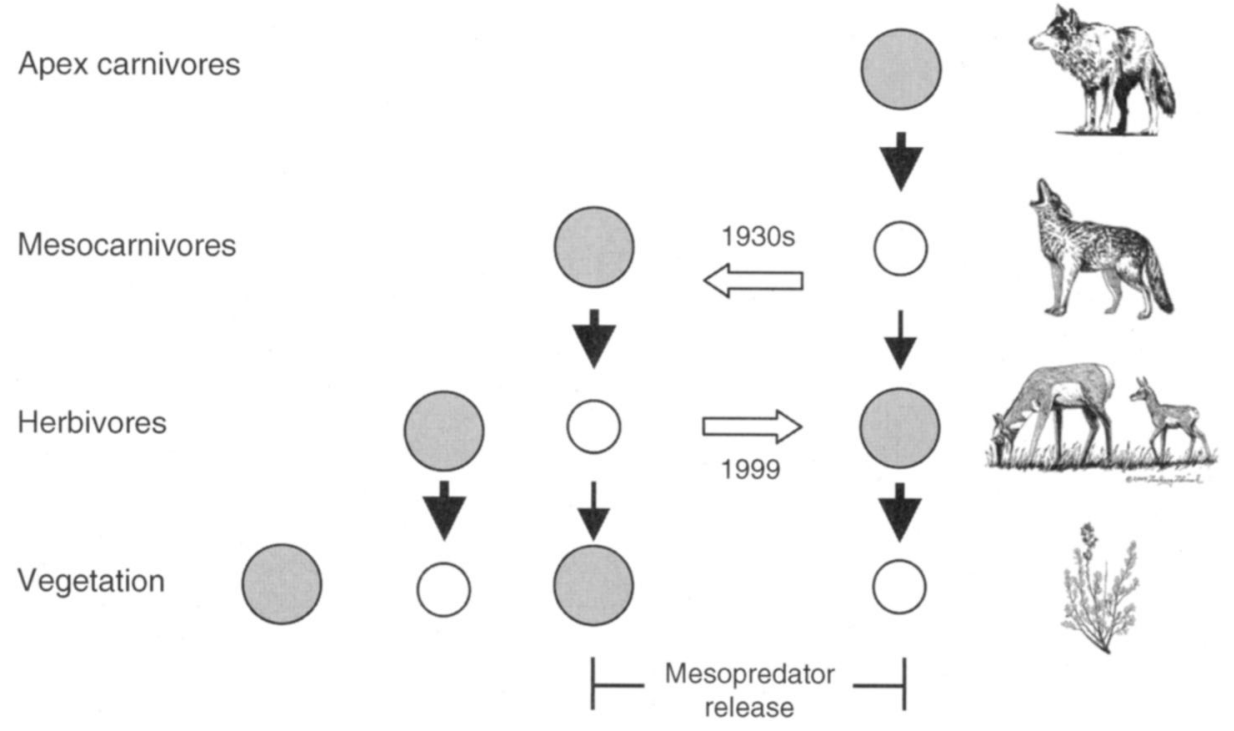

FIG. 1. Hypothesized relationships among trophic levels and changing trophic structure in Grand Teton National Park, Wyoming, USA. The weights of the arrows indicate the relative strengths of the effects. Relative abundance of organisms at each trophic level is indicated by the size of the circles. Mesocarnivore release in coyotes is thought to have occurred between the $1930 \mathrm{~s}$ and 1999 as a consequence of the extirpation of wolves in northwestern Wyoming.

carnivores from a four-tiered food chain shifts the trophic structure to a three-tiered system in which populations of secondary carnivores can increase (Fig. 1). This process, termed mesopredator release (Soulé et al. 1988), affects the persistence of both ground- and scrub-nesting birds through increased nest predation by striped skunks (Mephitis mephtis), raccoons (Procyon lotor), and grey foxes (Urocyon cinereoargenteus; Rogers and Caro 1998, Crooks and Soulé 1999).

Efforts to experimentally test predictions of the mesopredator release hypothesis using large carnivores have been hampered by an absence of appropriate baselines against which to measure changes, a lack of spatial and temporal controls, and logistical and ethical difficulties associated with large-scale manipulations of terrestrial communities (Polis et al. 2000, Steneck 2005). As a consequence, natural experiments involving the reintroduction or recolonization of large carnivores to systems where they have been absent offer important opportunities to evaluate the effects of apex predators (Gittleman and Gompper 2001).

The recolonization of wolves to Grand Teton National Park (GTNP), Wyoming, USA, is a case in point. Wolves were extirpated from northwestern Wyoming by the 1930s and were absent for nearly 70 years until their reintroduction to Yellowstone National Park (YNP) in 1995 (Smith et al. 2003). During late 1997, dispersing wolves from YNP recolonized GTNP (U.S. Fish and Wildlife Service, unpublished data). In the absence of wolves, coyotes (Canis latrans) were the dominant canid predator throughout the GYE. However, wolves and coyotes play different trophic roles in the system, as evidenced by size differences in their prey. Whereas wolves regularly take adult moose, elk (Cervus elaphus), and bison (Bison bison), coyotes prey disproportionately on small mammals and neonatal ungulates (Paquet 1992, Arjo et al. 2002).

To date, research on trophic cascades involving large carnivores has focused on cascades precipitated by direct predator-prey interactions (McLaren and Peterson 1994, Estes et al. 1998, Berger et al. 2001, Ripple et al. 2001, Terborgh et al. 2001, Fortin et al. 2005). Here we investigated potential direct and indirect effects of recolonizing wolves on pronghorn (Antilocapra americana) neonatal survival, as mediated by changes in the distribution and abundance of a mesocarnivore, coyotes, a major predator of neonate pronghorn (Fig. 1). Wolves exert top-down effects on coyotes through both interference competition (Peterson 1995a, Berger and Gese 2007), and intraguild predation (Polis and Holt 1992), an extreme form of interference competition in which the intraguild prey is consumed (M. Hebblewhite, personal communications). In the absence of wolves, coyote populations may therefore expand and threaten the persistence of pronghorn populations by limiting fawn recruitment. Following the mesopredator release hypothesis, we tested three primary predictions: (1) survival of pronghorn fawns is positively associated with wolf density, (2) survival of pronghorn fawns is negatively associated with coyote density, and (3) an inverse relationship characterizes coyote and wolf densities.

\section{Methods}

Study area and field sites

The study took place in Grand Teton National Park (GTNP), Wyoming, USA, and on the adjacent Bridger 


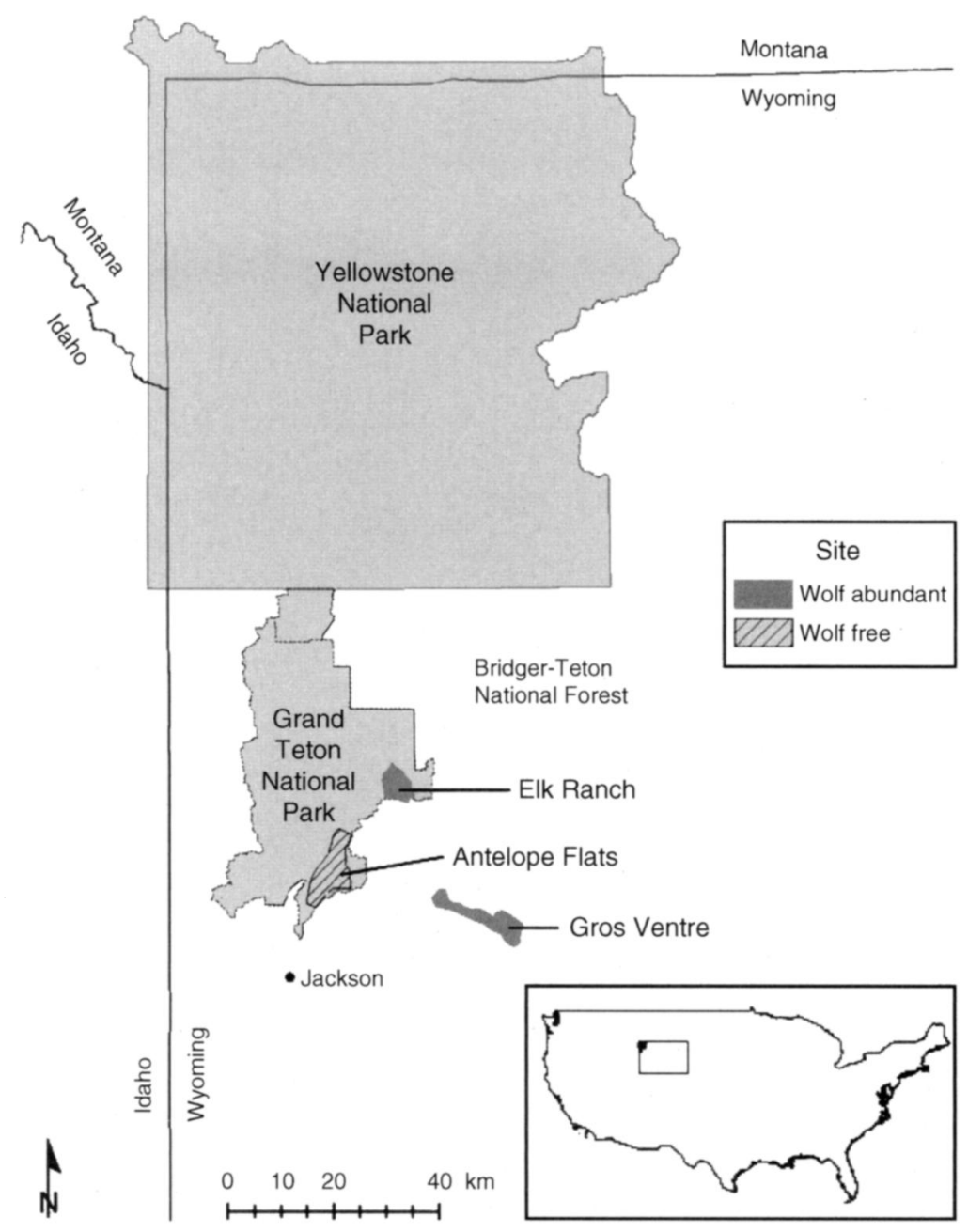

FIG. 2. Map showing the location of the Greater Yellowstone Ecosystem (GYE) in the western United States, the locations of study sites, and place names.

Teton National Forest (BTNF), from September 2001 to August 2004 (Fig. 2). The Park is bordered to the southeast by the National Elk Refuge (NER), a $100-\mathrm{km}^{2}$. area established in 1912 to provide secure winter habitat for elk (Smith et al. 2004). Elevation ranges from $1900 \mathrm{~m}$ to $>4000 \mathrm{~m}$. Within this broad array of protected lands, we selected three sites to exploit spatial and temporal variation in wolf distribution and abundance. The Elk Ranch site (ER) was used extensively by wolves when denning and pup rearing occurred (May-September) and periodically throughout the winter (NovemberApril), whereas the Gros Ventre site (GV) was used by wolves only during winter (Fig. 2). In contrast, the Antelope Flats (AF) site was not used by wolves during either season. All sites are characterized by shrub-steppe habitat dominated by big sagebrush (Artemesia tridentata), low sagebrush (A. arbuscula), Antelope bitterbrush (Purshia tridentata), and associated understory grasses of the genera Stipa, Bromus, and Poa. The Antelope Flats and Elk Ranch sites are periodically used for livestock grazing; consequently, some native vegetation at both sites has been replaced with smooth brome (Bromus inermis Leyss).

\section{Handling and monitoring of coyotes}

We monitored the movements of coyotes captured at the Elk Ranch and Antelope Flats sites. No coyotes were captured at the Gros Ventre site because restrictions on access during winter precluded recovery of coyote carcasses during the period when mortality due to wolf predation was most likely to occur (Peterson 1995a). We captured coyotes with padded foothold traps or with a net-gun fired from a helicopter (Gese et al. 1987). Coyotes were equipped with VHF collars with eight-hour mortality sensors (Advanced Telemetry Systems, Isanti, Minnesota, USA). Point and sequential locations obtained by ground and aerial telemetry were used to monitor survival and develop coyote home ranges (Gese et al. 1990). For ground locations, $\geq 3$ compass bearings with intersecting angles between $20^{\circ}$ 
and $160^{\circ}$ were used (White and Garrott 1990). Locations were estimated using the program Locate II (Pacer, Truro, Novia Scotia, Canada), and home ranges by the fixed-kernel density method (Worton 1989) with the "adehabitat" package (Calenge 2006) in program R (R Development Core Team 2006). To estimate home ranges, we used an ad hoc smoothing parameter $\left(h_{\mathrm{ad} \text { hoc }}\right)$ designed to prevent over- or under-smoothing. This method involves choosing the smallest increment of the reference bandwidth $\left(h_{\mathrm{ref}}\right)$ that results in a contiguous 95\% kernel home range polygon that contains no lacuna (i.e., $h_{\mathrm{ad} \text { hoc }}=0.9 \times h_{\text {ref }}, 0.8 \times h_{\text {ref }}$, etc.; J. G. Kie, unpublished data).

\section{Estimation of coyote densities}

We classified all coyotes as either residents or transients. Resident coyotes actively defended welldefined territories, whereas transients were not associated with a particular pack or territory. Densities of resident coyotes were assessed using a combination of spring (pre-whelping) pack sizes of known (i.e., radiocollared) individuals and indices of coyote abundance based on scat deposition surveys. Scat transects were located along $\sim 7.5 \mathrm{~km}$ of unimproved road at each site. Transects were initially cleared of all scats and then walked once/week for three weeks each spring and fall (Gese 2001). For known individuals, we determined pack sizes based on aerial and ground-based observations of animals displaying affiliative behaviors such as traveling, hunting, and resting together, or territorial maintenance (Camenzind 1978). For 2003 and 2004, we calculated resident coyote densities at the Elk Ranch and Antelope Flats sites by dividing the number of adult ( $>1$ year) coyotes in each pack by the size of the pack's home range using the $95 \%$ probability contour. Estimates for all packs at a site were then averaged to determine a site-specific mean and variance. We estimated transient coyote densities at the Elk Ranch and Antelope Flats sites based on the ratio of radiocollared transients to total radio-collared coyotes in 2003. We used 2003 as the baseline because we conducted extensive helicopter captures of coyotes that year and had the largest number of collars $(n=26)$ deployed. Densities of resident and transient coyotes were combined to produce estimates of total coyote density for both sites. Because we had radio collars on coyotes in too few packs to estimate numbers directly for 2002, we estimated coyote densities at the Elk Ranch and Antelope Flats sites based on the following relationship between coyote densities at both sites in 2003 and 2004 and assessments of relative abundance determined by scat deposition surveys (regression through the origin, $r^{2}=0.912, P=0.011$ ):

Coyote density $=1.644 \times$ scat deposition index.

For 2003 and 2004, coyote densities at the Gros Ventre site were estimated using Eq. 1. No estimate of coyote density was available for the Gros Ventre site in 2002 because we did not conduct scat deposition surveys there until the spring of 2003.

\section{Estimation of wolf densities}

Capture and collaring of wolves was handled by the U.S. Fish and Wildlife Service. Radio-tracking of wolves followed the same procedures as for coyotes. Seasonal wolf densities were based on known pack sizes for the summer (May-September) and winter (NovemberApril) periods (U.S. Fish and Wildlife Service, unpublished data). These periods corresponded to seasonal shifts in centers of activity between the wolf pack's den site in GTNP and the state-run elk feed grounds in the BTNF. Summer density estimates were based on the number of adults in the pack, whereas winter estimates were based on the number of adults and pups. Pups were included in the latter estimates because their presence would increase competition at kills and, thus, might make wolves less tolerant of coyotes at carcasses. To calculate seasonal wolf densities, we divided the number of wolves in the pack each season by the size of the pack's seasonal home range. Seasonal home ranges for wolves were estimated using the same procedures as for coyotes.

\section{Capture and monitoring of neonate pronghorn}

We monitored the survival of pronghorn fawns captured at the Antelope Flats site during June 20022004, and at the Gros Ventre and Elk Ranch sites during June 2003-2004. All fawns were equipped with expandable, breakaway VHF radio-collars with four-hour mortality sensors (mass $\sim 60$ g; Advanced Telemetry Systems, Isanti, Minnesota, USA), weighed using a canvas sling hung from a spring scale, and aged based on observation of birth or the degree of desiccation of the umbilicus (Byers and Moodie 1990). Fawns were monitored daily for the first 60 days of life, and then weekly until the fall migration.

\section{Statistical analysis}

We evaluated the relationships between coyote density and pronghorn fawn survival, wolf density and fawn survival, and coyote density and wolf density using correlation analysis. We used correlation analysis rather than simple linear regression or multivariate regression because for each bivariate comparison, values of the independent variable were subject to measurement error; thus, we did not meet the assumptions of regression analysis (Gotelli and Ellison 2004). Furthermore, the hypothesized relationship between wolf density and fawn survival was indirect and mediated by changes in coyote density; thus, we expected that the relationship between wolf density and fawn survival would be confounded by the coyote variable in a multivariate analysis (Cohen et al. 2003). Although correlation analysis uses a slightly different line-fitting algorithm that minimizes both the vertical and horizontal (i.e., $x$ and $y$ ) distance of each point from the regression line, 


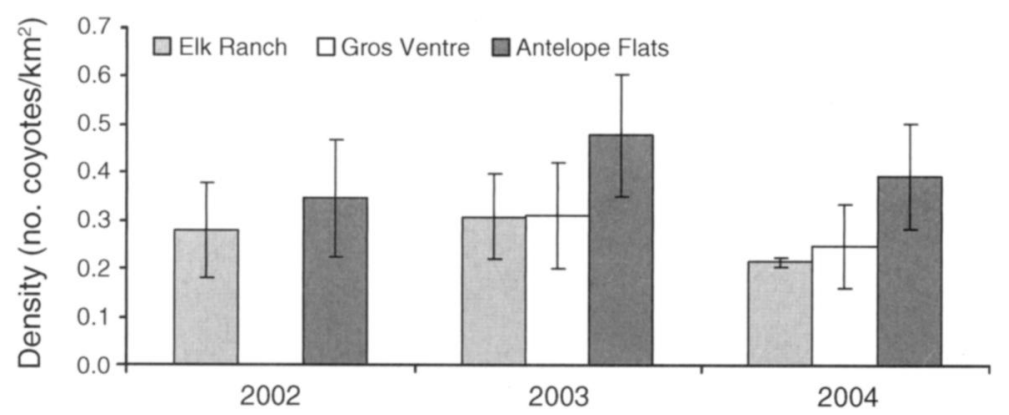

FIG. 3. Coyote densities (resident and transient combined) at the three field sites in northwestern Wyoming, 2002-2004. Values are means $\pm 2 \mathrm{SE}$.

the correlation coefficient is identical to that produced by linear regression (Gotelli and Ellison 2004).

We estimated survival of pronghorn fawns for the first 60 days of life using a known fate model in Program MARK (White and Burnham 1999). The analysis was based on individual encounter histories, with a single encounter for each cohort that indicated whether the fawn survived or died during the 60-day period. We evaluated 37 models to assess the effects of individual covariates (gender and birthweight) and group covariates (coyote density, summer wolf density, and winter wolf density) on fawn survival. For fawns that were not newborns at capture, we calculated mass at birth based on the following relationship (modified from Byers 1997) as follows:

birthweight $=$ weight at capture -0.2446 (age in days) .

The global model considered was $\left(\hat{S}_{\mathrm{g}+\mathrm{m}+\mathrm{c}+\mathrm{sw}+\mathrm{ww}}\right)$, where $\hat{S}$ was estimated survival probability, $\mathrm{g}$ was gender, $\mathrm{m}$ was birthweight, $\mathrm{c}$ was coyote density, sw was summer wolf density, and ww was winter wolf density. We also tested models that included dummy variables for site (s), wolf-free site (wf), and year (y) to examine possible differences in fawn survival among sites and years that were not captured by the group covariates. We used Akaike's Information Criterion adjusted for small sample sizes $\left(\mathrm{AIC}_{\mathrm{c}}\right)$ and Akaike weights to rank models (Burnham and Anderson 2002). Using the top-ranked (i.e., minimum $\mathrm{AIC}_{\mathrm{c}}$ ) model from the initial analyses, we fit one additional model to assess whether an irruption in white-tailed jackrabbits (Lepus townsendii) at the Gros Ventre site might account for an observed increase in fawn survival in 2004.

\section{RESUl.TS \\ Coyote captures}

We radio-collared 38 coyotes at the Elk Ranch and Antelope Flats sites. The percentage of coyotes classified as residents and transients was $51 \%(n=18)$ and $49 \%(n$ $=17$ ), respectively. In three cases, the animal died too soon after capture for its status to be determined. In addition to the three coyotes of unknown status, seven coyotes were censored from all analyses because they dispersed to areas outside our field sites.

\section{Coyote and wolf densities}

Total coyote densities were highest at the Antelope Flats site in $2003\left(0.479 \pm 0.065\right.$ coyotes $\left./ \mathrm{km}^{2}\right)$ and lowest at the Elk Ranch site in $2004(0.215 \pm 0.002$ coyotes $/ \mathrm{km}^{2}$; Fig. 3). Densities of resident coyotes at the Antelope Flats site $(\bar{X}=0.251 \pm 0.025)$ were similar to those at the Elk Ranch site $(\bar{X}=0.232 \pm 0.029$, Student's $t$ test, $P=0.687)$, whereas transient densities were significantly lower at Elk Ranch $(\bar{X}=0.188 \pm 0.019$ vs. $\bar{X}$ $=0.039 \pm 0.005$, Student's $t$ test, $P<0.001$; Fig. 4). With respect to wolves, densities were highest at the Elk Ranch site during the winter of $2003\left(0.061\right.$ wolves $\left./ \mathrm{km}^{2}\right)$, and lowest at the Elk Ranch site during the summer of 2003 ( 0.015 wolves $/ \mathrm{km}^{2}$; Fig. 5). Wolves made only rare visits to the Antelope Flats site; thus, wolf density at this site was effectively zero for all years.

\section{Pronghorn neonatal survival}

We included 108 marked individuals (19 in 2002, 44 in 2003 , and 45 in 2004) in the analysis of fawn survival, distributed by site as follows: $\mathrm{ER}=27, \mathrm{GV}=30$, and $\mathrm{AF}$ $=51$. On the basis of minimum $\mathrm{AIC}_{\mathrm{c}}$, the best model of fawn survival contained parameters for gender, birthweight, and coyote density (Table 1). However, the topranked model had just $13.7 \%$ of the Akaike weights (Table 1), indicating there was considerable uncertainty as to which of the highly ranked candidate models was

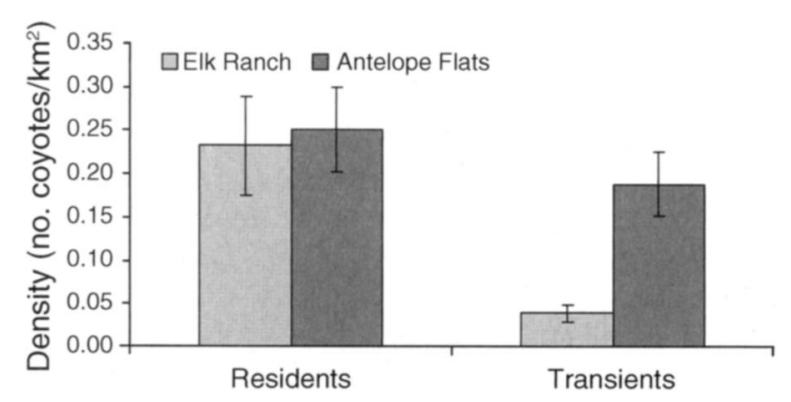

Fig. 4. Comparison of resident and transient coyote densities at sites with radio-collared coyotes in northwestern Wyoming, 2003-2004. Values are means \pm 2 SE. 


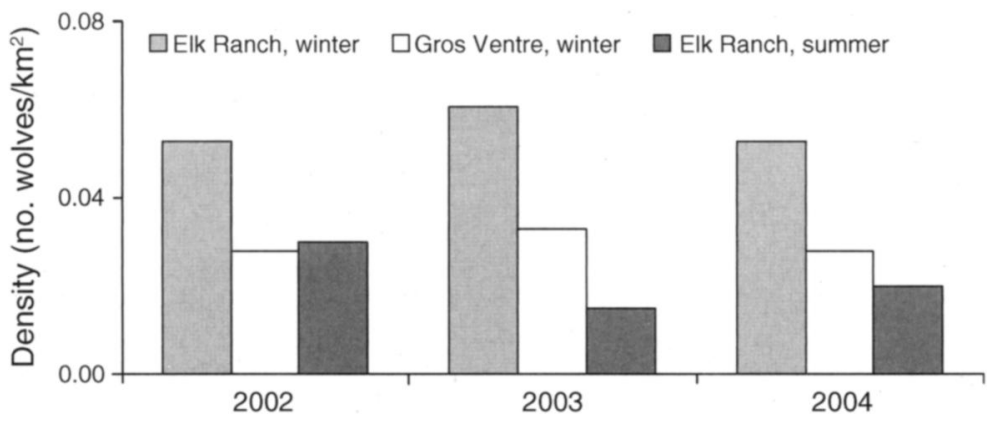

FIG. 5. Seasonal wolf densities at two sites in northwestern Wyoming, 2002-2004. The Antelope Flats site is not shown because wolves did not use the site.

actually the best predictor of fawn survival (Burnham and Anderson 2002). Coyote density appeared in all nine of the top-ranked models, with a cumulative Akaike weight of $62.4 \%$ (Table 1). Thus, the overall importance of this single variable likely contributed to modelselection uncertainty, as a model that included only coyote density was nearly as good $\left(\Delta \mathrm{AIC}_{\mathrm{c}}=1.311\right)$ at predicting fawn survival as one that also included both gender and birthweight (Table 1). Models that included variables for coyote and wolf densities outperformed comparable models that suggested that fawn survival differed among the sites independent of coyote and wolf densities (Table 1).

Model-averaged survival estimates (Burnham and Anderson 2002) during the first 60 days of life ranged from a low of $\hat{S}=0.049$ at the Antelope Flats site in 2003 , to a high of $\hat{S}=0.440$ at the Elk Ranch site in 2004 (Table 2). Based on the parameter estimates from the top-ranked model, fawn survival was negatively correlated with coyote density $(\beta=-12.313 \pm 3.875$, Wald test, $P=0.002$ ) and positively correlated with birthweight $(\beta=0.413 \pm 0.263$, Wald test, $P=0.116)$. Survival of male fawns was lower than for females $(\beta=$ $-0.496 \pm 0.266$, Wald test, $P=0.062$ ). Based on the results of correlation analysis, fawn survival was negatively correlated with coyote density $(r=-0.882$, $P=0.009$; Fig. $6 \mathrm{a}$ ) and positively correlated with winter wolf density $(r=0.791, P=0.034$; Fig. $6 \mathrm{~b})$; and the relationship between coyote and winter wolf densities was negative ( $r=-0.740, P=0.036$; Fig. $6 c)$. Summer

TABLE 1. Model selection results for survival $(S)$ of pronghorn fawns during the first 60 days of life at three study sites in northwestern Wyoming, USA, 2002-2004.

\begin{tabular}{lcccccr}
\hline \multicolumn{1}{c}{ Model } & $K \dagger$ & $\mathrm{AIC}_{\mathrm{c}}$ & $\Delta \mathrm{AIC}_{\mathrm{c}}$ & Akaike weight & Model likelihood & Deviance \\
\hline$S_{\mathrm{g}+\mathrm{m}+\mathrm{c}}$ & 4 & 107.003 & 0.000 & 0.137 & 1.000 & 98.611 \\
$S_{\mathrm{g}+\mathrm{c}}$ & 3 & 107.357 & 0.353 & 0.115 & 0.838 & 101.124 \\
$S_{\mathrm{c}}$ & 2 & 108.314 & 1.311 & 0.071 & 0.519 & 104.198 \\
$S_{\mathrm{m}+\mathrm{c}}$ & 3 & 108.566 & 1.563 & 0.063 & 0.458 & 102.333 \\
$S_{\mathrm{g}+\mathrm{m}+\mathrm{c}+\mathrm{j}}$ & 5 & 108.804 & 1.800 & 0.056 & 0.407 & 98.209 \\
$S_{\mathrm{g}+\mathrm{m}+\mathrm{c}+\mathrm{sw}}$ & 5 & 109.014 & 2.011 & 0.050 & 0.366 & 98.420 \\
$S_{\mathrm{g}+\mathrm{m}+\mathrm{c}+\mathrm{ww}}$ & 5 & 109.122 & 2.119 & 0.048 & 0.347 & 98.528 \\
$S_{\mathrm{g}+\mathrm{c}+\mathrm{sw}}$ & 4 & 109.282 & 2.278 & 0.044 & 0.320 & 100.889 \\
$S_{\mathrm{g}+\mathrm{c}+\mathrm{ww}}$ & 4 & 109.431 & 2.428 & 0.041 & 0.297 & 101.039 \\
$S_{\mathrm{wf}+\mathrm{g}+\mathrm{m}}$ & 4 & 109.729 & 2.725 & 0.035 & 0.256 & 101.336 \\
$S_{\mathrm{wf}+\mathrm{g}}$ & 3 & 109.772 & 2.769 & 0.034 & 0.250 & 103.539 \\
$S_{\mathrm{wf}}$ & 2 & 109.829 & 2.826 & 0.033 & 0.243 & 105.714 \\
$S_{\mathrm{c}+\mathrm{sw}}$ & 3 & 109.873 & 2.870 & 0.033 & 0.238 & 103.640 \\
$S_{\mathrm{c}+\mathrm{ww}}$ & 3 & 110.364 & 3.360 & 0.026 & 0.186 & 104.131 \\
$S_{\mathrm{g}+\mathrm{m}+\mathrm{c}+\mathrm{ww}+\mathrm{sw}}$ & 6 & 110.590 & 3.587 & 0.023 & 0.166 & 97.750 \\
$S_{\mathrm{wf}+\mathrm{y}+\mathrm{g}+\mathrm{m}}$ & 6 & 110.728 & 3.725 & 0.021 & 0.155 & 97.888 \\
$S_{\mathrm{g}+\mathrm{c}+\mathrm{ww}+\mathrm{sw}}$ & 5 & 110.737 & 3.734 & 0.021 & 0.155 & 100.143 \\
$S_{\mathrm{c}+\mathrm{ww}+\mathrm{sw}}$ & 4 & 110.897 & 3.894 & 0.020 & 0.143 & 102.505 \\
$S_{\mathrm{wf}+\mathrm{g}+\mathrm{m}+\mathrm{c}+\mathrm{ww}}$ & 6 & 111.151 & 4.148 & 0.017 & 0.126 & 98.311 \\
$S_{\mathrm{m}+\mathrm{c}+\mathrm{ww}+\mathrm{sw}}$ & 5 & 111.302 & 4.298 & 0.016 & 0.117 & 100.708 \\
$S_{\mathrm{s}+\mathrm{g}+\mathrm{m}}$ & 5 & 111.910 & 4.906 & 0.012 & 0.086 & 101.315 \\
$S_{\mathrm{s}+\mathrm{g}}$ & 4 & 111.921 & 4.917 & 0.012 & 0.086 & 103.528 \\
$S_{\mathrm{s}}$ & 3 & 111.921 & 4.918 & 0.012 & 0.086 & 105.688 \\
$S_{\mathrm{g}+\mathrm{m}+\mathrm{ww}}$ & 4 & 112.300 & 5.297 & 0.010 & 0.071 & 103.908 \\
$S_{\mathrm{s}+\mathrm{m}}$ & 4 & 112.311 & 5.308 & 0.010 & 0.070 & 103.919 \\
& & & & & &
\end{tabular}

Notes: Although we tested 37 models, we present results only for models with Akaike weights $\geq$ 0.01 . Abbreviations are: $g$, gender; $m$, birthweight; $c$, coyote density; $j$, an irruption in the population of white-tailed jackrabbits; sw, summer wolf density; ww, winter wolf density; wf, wolffree site; s, site; and y, year.

$\dagger$ Number of estimable parameters, including the intercept. 
TABle 2. Model-averaged estimates ( $\hat{S}$, with SE and confidence limits) of pronghorn fawn survival during the first 60 days of life at three study sites in northwestern Wyoming, 2002-2004.

\begin{tabular}{|c|c|c|c|c|}
\hline Site & $\hat{S}$ & SE & $\begin{array}{c}95 \% \\
\text { lower } \\
\text { CL }\end{array}$ & $\begin{array}{c}95 \% \\
\text { upper } \\
\text { CL }\end{array}$ \\
\hline \multicolumn{5}{|c|}{ Sites with coyotes and wolves } \\
\hline Gros Ventre 2003 & 0.255 & 0.071 & 0.141 & 0.417 \\
\hline Gros Ventre 2004 & 0.390 & 0.094 & 0.228 & 0.581 \\
\hline Elk Ranch 2003 & 0.259 & 0.085 & 0.127 & 0.454 \\
\hline Elk Ranch 2004 & 0.440 & 0.112 & 0.244 & 0.657 \\
\hline \multicolumn{5}{|c|}{ Site with coyotes and no wolves } \\
\hline Antelope Flats 2002 & 0.149 & 0.055 & 0.070 & 0.291 \\
\hline Antelope Flats 2003 & 0.049 & 0.037 & 0.011 & 0.193 \\
\hline Antelope Flats 2004 & 0.097 & 0.043 & 0.040 & 0.218 \\
\hline
\end{tabular}

wolf density was also positively correlated with fawn survival $(r=0.447, P=0.314)$, and negatively correlated with coyote density $(r=-0.521, P=0.185)$, but neither relationship was statistically significant.

\section{Discussion}

\section{Did wolves precipitate a trophic-level interaction?}

The traditional trophic cascades model is based on consumer-resource interactions at each link in a food chain (Paine 1980). Consequently, research on top-down effects resulting from reintroductions of large carnivores has focused on cascades precipitated by direct predatorprey interactions (Berger et al. 2001, Ripple et al. 2001, Terborgh et al. 2001, Fortin et al. 2005, Hebblewhite et al. 2005), to the extent that alternative top-down pathways through which large carnivores influence systems have largely been ignored. However, large carnivores such as wolves also exert top-down forcing on systems through interference competition and intraguild predation, and these interactions may also be important mediators of cascades.

That wolves precipitated a species-level trophic cascade (sensu Polis 1999) is evidenced by more than a four-fold difference in neonatal survival at sites used by wolves during either winter, or both winter and summer (Table 2). The corresponding negative correlation between coyote and wolf densities supports the hypothesis that interspecific interactions between these species facilitated the observed increase in pronghorn fawn survival. Whereas mean densities of resident coyotes were similar between wolf-free and wolf-abundant sites $\left(\bar{X}=0.251 \pm 0.025\right.$ coyotes $/ \mathrm{km}^{2}$ and $\bar{X}=0.232 \pm 0.29$ coyotes $/ \mathrm{km}^{2}$, respectively; Student's $t$ test, $P=0.687$ ), the mean abundance of transient coyotes was significantly lower in areas used by wolves $(\bar{X}=0.188 \pm 0.019$ coyotes $/ \mathrm{km}^{2}$ vs. $\bar{X}=0.039 \pm 0.005$ coyotes $/ \mathrm{km}^{2}$; Student's $t$ test, $P<0.001)$. Thus, differential effects of wolves on solitary coyotes may be an important mechanism by which wolves limit coyote populations (Berger and Gese 2007). This hypothesis is further supported by differences in mortality rates and cause- specific mortality of resident and transient coyotes in GTNP between 2001 and 2004. Annual mortality rates of resident coyotes were $26 \%$ at the wolf-free site, and $27 \%$ at the wolf-abundant site (Berger and Gese 2007). In contrast, those of transient coyotes averaged $46 \%$ and $66 \%$ in wolf-free and wolf-abundant areas, respectively (Berger and Gese 2007). And, whereas no resident coyote were killed by wolves, $67 \%$ of transient coyote deaths resulted from predation, with wolves accounting for $83 \%$ of predation-related mortality (Berger and Gese 2007).

Despite the strong correlations between coyote densities, winter wolf densities, and fawn survival, the variable for winter wolf density did not appear in any of the highest ranked models (i.e., models with $\mathrm{AIC}_{\mathrm{c}}<2$; Table 1; Burnham and Anderson 2002). This supports the hypotheses that the effect of wolves on fawn survival is largely indirect and mediated by differences in coyote densities among the sites, as inclusion of the winter wolf density variable in the model explained no additional variation in fawn survival beyond that already captured by the coyote density variable.

Reductions in coyote densities in GTNP have not been as large as those documented elsewhere. For instance, coyote densities were reportedly reduced by $50 \%$ in YNP following wolf reintroduction, and coyotes were extirpated from Isle Royale within eight years of the arrival of wolves in the late 1940s (Krefting 1969, Smith et al. 2003). In contrast, coyote abundance in GTNP has declined by $\sim 33 \%$ based on differential population densities at sites with and without wolves.

Several factors likely contributed to the lesser reduction in coyote densities we detected. For instance, the small size of the area $\left(2314 \mathrm{~km}^{2}\right)$ and corresponding lack of refugia are thought to have contributed to the rapid extirpation of coyotes from Isle Royale (Peterson $1995 b$ ). In contrast, GTNP is not spatially closed and a single wolf pack occupied only a small portion of the Park during the course of this study. Thus, it is likely the coyote population in GTNP will experience additional reductions as the wolf population continues to increase and wolves expand into areas of the Park from which they are currently absent. Furthermore, competition between wolves and coyotes may have been mediated by a relative abundance of prey. Elk densities in GTNP are in the neighborhood of $6 \mathrm{elk} / \mathrm{km}^{2}$, rising to $\sim 76 \mathrm{elk} / \mathrm{km}^{2}$ during winter when elk are concentrated on feed grounds (based on data from Smith et al. 2004). As elk are the primary prey of wolves (Smith et al. 2003), their relative abundance may increase wolf tolerance of coyotes at carcasses where agonistic encounters are most likely to occur (Switalski 2003).

\section{Effects of changes in neonatal survival and pronghorn population density}

Demographic modeling indicates that the observed differences in fawn survival between wolf-free and wolfabundant areas were sufficient to alter the trajectory of 
the pronghorn population in GTNP from a declining to an increasing trend (Berger 2007). Still, for increases in summer survival of pronghorn fawns to result in an actual increase in the pronghorn population in GTNP, several conditions must be met. First, mortality from coyote predation must be additive and not compensatory (Boyce et al. 1999). We found no evidence of any compensatory predation-related mortality in radiocollared fawns. (Berger 2007), and prospects for compensatory density-dependent mortality appear unlikely given that the current pronghorn population in the Park is $<10 \%$ of its historical size (Berger 2003). Second, fawns surviving the summer must also survive their first winter to be recruited into the population as yearlings. Whereas prospects for density-dependent population regulation appear unlikely on the summer range, conditions on the winter range, located on lands managed by the Bureau of Land Management some $190 \mathrm{~km}$ beyond Park borders, strongly differ. Habitat designated "crucial winter range" for pronghorn (Wyoming Game and Fish Department, Cheyenne, Wyoming, USA) is currently undergoing rapid conversion due to development of natural gas wells. As overwinter survival rates of juvenile ungulates are typically lower than those of adults (Gaillard et al. 1998), this age class is likely to be differentially susceptible to any reductions in carrying capacity stemming from habitat loss. Thus, increases in summer survival of fawns may be offset by increases in overwinter mortality, resulting in no net change, or even a decrease, in the pronghorn population. Third, fawns surviving their first winter must complete the return migration the following spring to be recruited into the Park population. Telemetry data indicate that approximately $80-85 \%$ of fawns return to the Park each year, with the remainder dispersing to other summer ranges (K. M. Berger, unpublished data). Although competition for forage could alter the proportion of fawns showing philopatry to their natal range, this possibility appears unlikely given the low population density.

\section{Contributing factors}

The detection of trophic cascades in terrestrial systems has often been elusive because interactions between species can be weak and diffuse (Polis et al. 2000). Although the food web in Greater Yellowstone is complex due to a large number of sympatric carnivores and herbivores (Berger and Smith 2005), the focal chain we studied was relatively simple in structure. Adult pronghorn are effectively predator-free owing to their speed (Byers 1997), and while bobcats (Lynx rufus) and golden eagles (Aquila chrysaetos) are important predators of fawns in some areas (Beale and Smith 1973, Byers 1997), both species occur at low densities at our field sites (K. M. Berger, personal observations). Wolves do kill pronghorn fawns opportunistically, but their large body mass $(18-80 \mathrm{~kg})$ relative to coyotes (11-18
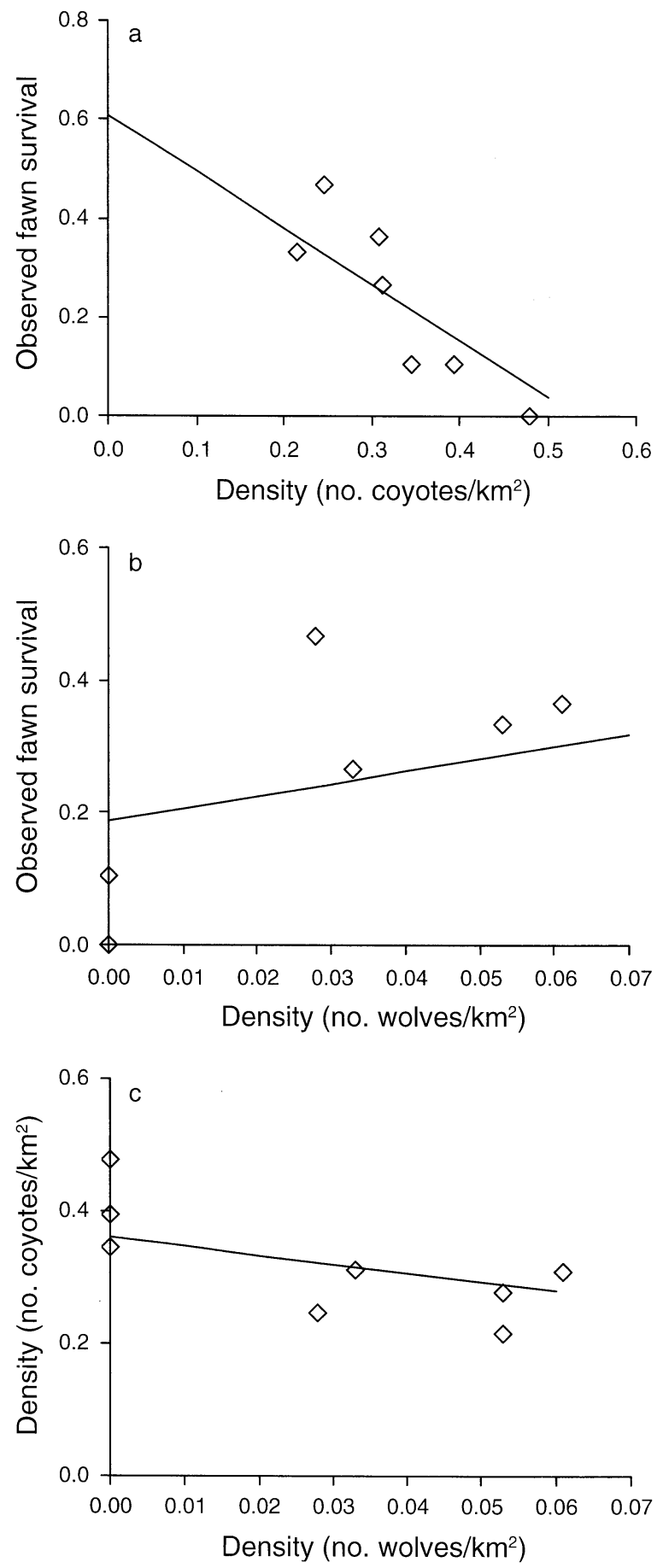

FIG. 6. Correlations between (a) observed pronghorn fawn survival and coyote density, (b) observed pronghorn fawn survival and wolf density, and (c) coyote and wolf densities at three sites in northwestern Wyoming, 2002-2004. Note that the lines are fitted using correlation analysis (Gotelli and Ellison 2004), which uses a slightly different line-fitting algorithm than linear regression. 
$\mathrm{kg}$ ) makes it energetically inefficient for wolves to hunt systematically for pronghorn neonates (3-4 kg) with the same intensity as coyotes (Gittleman 1985, Byers 1997). Consequently, coyotes accounted for $71 \%$ of total mortality, and $97 \%$ of predation-related mortality, of pronghorn fawns in our system (Berger 2007). Thus, effects of changes in coyote predation on fawn survival may have been easier to discern due to a lack of compensatory predation.

Anthropogenic changes in pronghorn population densities may have contributed to the strength of the interaction between coyotes and pronghorn. Specifically, populations that have been reduced by severe winter weather or over-harvesting by humans may experience poor recruitment resulting from sustained levels of predation (Gasaway et al. 1983). Although a few thousand pronghorn have historically summered in the Park (Deloney 1948), the population was reduced in the late 1800 s as a consequence of market hunting. Since the turn of the 20th century, the population has never numbered more than the low 400 s, and is currently $\sim 200$ animals (Berger 2003). Thus, relatively high coyote densities coupled with relatively low densities of pronghorn may allow coyotes to consume nearly all of the estimated $\sim 150$ pronghorn fawns produced in the Park each summer (Berger 2007).

Populations of migratory ungulates may be regulated by bottom-up forces when carnivore densities are determined by the supply of resident herbivores (Sinclair 1995). However, alternative prey may maintain stable predator populations or enable high densities of predators (Polis 1999). Because pronghorn females rely on reproductive synchrony and predator swamping to maximize fitness (Gregg et al. 2001), low pronghorn densities relative to the number of coyotes sustained by resident herbivores such as elk may allow coyotes to effectively regulate the pronghorn population by consuming a large proportion of the fawns produced each year (i.e., a predator-pit; Holling 1965). The possibility of a predator-pit is suggested by a positive relationship between fawn survival and pronghorn population density $\left(r^{2}=0.257, P=0.004\right)$ in GTNP between 1981 and 2004 (Berger 2007).

The strength of the interaction between coyotes and pronghorn may also be enhanced by a lack of alternative prey. Notably, although jackrabbits are an important component of coyote diets in some areas (Clark 1972), black-tailed jackrabbits (Lepus californicus) do not occur in northwestern Wyoming (Best 1996), and white-tailed jackrabbits are functionally, if not actually, extinct in GTNP (Berger et al. 2006). Jackrabbits and pronghorn neonates are similarly sized $(3-4 \mathrm{~kg})$, and the absence of alternative prey may increase coyotes' dependence on pronghorn fawns at a critical juncture when adult coyotes are experiencing energetic demands associated with provisioning pups.

An irruption in the jackrabbit population at the Gros Ventre site in 2004 provided an opportunity to explore this idea. Specifically, we included a dummy variable representing the jackrabbit irruption in the model of estimated fawn survival to test for evidence of additional variation in survival that was not adequately explained by the top-ranked model. The model that included the jackrabbit variable accounted for $5.6 \%$ of the Akaike weights (Table 1), suggesting some support for our hypothesis (Burnham and Anderson 2002). However, this model had a similar deviance to the top-ranked model, and the $\Delta \mathrm{AIC}_{\mathrm{c}} \approx 2$ was a result of adding another parameter to the model that explained little additional variation (Burnham and Anderson 2002). Thus, we concluded there was weak evidence that an irruption in the jackrabbit population contributed to an increase in fawn survival at the GV site in 2004.

Finally, the strength of the interaction between coyotes and pronghorn may be enhanced by changes in coyote densities resulting from human alteration of resource availability. Specifically, whereas most elk migrated out of GTNP and the surrounding area prior to human settlement, currently an average of 7500 elk now winter just south of GTNP on the National Elk Refuge (Smith et al. 2004). Overwinter mortality of elk on the NER averages 2-3\% (Smith 1991), resulting in an estimated $41000 \mathrm{~kg}$ of gross carcass biomass during a typical winter (i.e., 7500 elk $\times 2 \%$ mortality $\times 273 \mathrm{~kg} / \mathrm{elk}$ $=40950 \mathrm{~kg}$ ). Coyotes are opportunistic, generalist predators and scavengers and their densities are limited by the availability of prey during winter (Gese 2004). Thus, the availability of abundant elk carcasses on the NER is likely to subsidize the winter diets of coyotes and maintain the population in GTNP at artificially elevated densities. Furthermore, because elk feeding suppresses temporal variation in elk mortality associated with mild and harsh winters, carcasses on the NER provide a stable food supply that may buffer the coyote population from weather-dependent fluctuations. That elk carrion is an important resource for coyotes is suggested by the coyote "aggregations" that form on the NER each winter (Camenzind 1978). Indeed, the availability of this seasonal food subsidy results in the seasonal migration of transient and resident coyotes from both the ER and AF sites (K. M. Berger, unpublished data).

\section{Conclusions}

In contrast with previous studies, the changes in herbivore populations that we observed resulted not from direct predation by a top carnivore, but rather as a result of indirect effects mediated by changes in mesocarnivore abundance. The strong, negative correlations between coyote and wolf densities, and coyote densities and fawn survival, support the hypothesis that mesopredator release of coyotes, resulting from the extirpation of wolves throughout much of North America, contributes to high rates of coyote predation on pronghorn fawns observed in some areas. Thus, from both management and conservation perspectives wolf restoration holds promise for reducing coyote predation 
rates on neonatal ungulates such as pronghorn, mule deer (Odocoileus hemionus), and white-tailed deer (Odocoileus virginianus). In particular, we expect that similar cascades should emerge in places such as Yellowstone National Park, where the pronghiorn population has declined precipitously in recent years, coyote predation on pronghorn fawns is high, and wolves have reportedly reduced the coyote population by as much as 50\% (Caslick 1998, Smith et al. 2003). Our results provide strong evidence of a species-level trophic cascade precipitated by wolf recolonization in the southern GYE, and support a growing body of research demonstrating the importance of top-down forces in structuring the dynamics of consumer-resource interactions in terrestrial systems (McLaren and Peterson 1994, Berger et al. 2001, Ripple et al. 2001, Terborgh et al. 2001, Fortin et al. 2005).

\section{ACKNOWLEDGMENTS}

This work was funded by Grand Teton National Park and the Biological. Resources Division of the U.S. Geological Survey under Cooperative Agreement 01CRAG0031, the Wildlife Conservation Society, the USDA National Wildlife Research Center at Utah State University, the NatureFlight Foundation, and the Earth Friends Foundation. We thank Renee Wulff, Noah Weber, Mike Nordell, and the many volunteers who assisted with fawn captures and data collection. J. Estes, D. Rosenberg, M. Conner, P. Budy, and J. Bissonette provided helpful comments. Research protocols were approved by Institutional Animal Care and Use Committees at Utah State University (Approval \#1111) and the National Wildlife Research Center (QA-1193).

\section{Literature Cited}

Arjo, W. M., D. H. Pletscher, and R. R. Ream. 2002. Dietary overlap between wolves and coyotes in northwestern Montana. Journal of Mammalogy 83:754-766.

Beale, D. M., and A. D. Smith. 1973. Mortality of pronghorn antelope fawns in western Utah. Journal of Wildlife Management 37:343-352.

Berger, J., K. M. Berger, P. F. Brussard, R. Gibson, J. Rachlow, and A. Smith. 2006. Where have all the rabbits gone? Summary and Recommendations. Grand Teton National Park, September 23-24, 2005. Wildlife Conservation Society, Bozeman, Montana, USA.

Berger, J., and D. W. Smith. 2005. Restoring functionality in Yellowstone with recovering carnivores: gains and uncertainties. Pages 100-109 in J. C. Ray, K. H. Redford, R. S. Steneck, and J. Berger, editors. Large carnivores and the conservation of biodiversity. Island Press, Washington, D.C., USA.

Berger, J., P. B. Stacey, L. Bellis, and M. P. Johnson. 2001. A mammalian predator-prey imbalance: grizzly bear and wolf extinction affect avian neotropical migrants. Ecological Applications 11:947-960.

Berger, K. M. 2003. Pronghorn in peril. Wildlife Conservation 8:38-41.

Berger, K. M. 2006. Carnivore-livestock conflicts: effects of subsidized predator control and economic correlates on the sheep industry. Conservation Biology 20:751-761.

Berger, K. M. 2007. Conservation implications of food webs involving wolves, coyotes, and pronghorn. Dissertation. Utah State University, Logan, Utah, USA.

Berger, K. M., and E. M. Gese. 2007. Does interference competition with wolves limit the distribution and abundance of coyotes? Journal of Animal Ecology 76:1075-1085.
Best, T. L. 1996. Lepus californicus. Mammalian species 530:110.

Boyce, M. S., A. R. E. Sinclair, and G. C. White. 1999. Seasonal compensation of predation and harvesting. Oikos 87:419-426.

Burnham, K. P., and D. R. Anderson. 2002. Model selection and multimodel inference. Second edition. Springer-Verlag, New York, New York, USA.

Byers, J. A. 1997. American pronghorn: social adaptations and the ghosts of predators past. University of Chicago Press, Chicago, Illinois, USA.

Byers, J. A., and J. D. Moodie. 1990. Sex-specific maternal investment in pronghorn, and the question of a limit on differential provisioning in ungulates. Behavioral Ecology and Sociobiology 26:157-164.

Calenge, C. 2006. The package adehabitat for the R software: a tool for the analysis of space and habitat use by animals. Ecological Modelling 197:516-519.

Camenzind, F. J. 1978. Behavioral ecology of coyotes on the National Elk Refuge, Jackson, Wyoming. Pages 267-294 in M. Bekoff, editor. Coyote: biology, behavior, and management. Academic Press, New York, New York, USA.

Caslick, J. W. 1998. Yellowstone pronghorns: relict herd in a shrinking habitat. Yellowstone Science 6(4):20-24.

Clark, F. W. 1972. Influence of jackrabbit density on coyote population change. Journal of Wildlife Management 36:343356.

Cohen, J., P. Cohen, S. G. West, and L. S. Aiken. 2003. Applied multiple regression/correlation analysis for the behavioral sciences. Third edition. Lawrence Erlbaum, Mahwah, New Jersey, USA.

Crooks, K. R., and M. E. Soulé. 1999. Mesopredator release and avifaunal extinctions in a fragmented system. Nature 400:563-566.

Deloney, W. C. 1948. Passing of the antelope in the Jackson Hole. Jackson Hole Courier, 12 February 1948.

Estes, J. A., M. T. Tinker, T. M. Williams, and D. F. Doak. 1998. Killer whale predation on sea otters linking oceanic and nearshore ecosystems. Science 282:473-476.

Fortin, D., H. L. Beyer, M. S. Boyce, D. W. Smith, T. Duchesne, and J. S. Mao. 2005. Wolves influence elk movements: behavior shapes a trophic cascade in Yellowstone National Park. Ecology 86:1320-1330.

Fretwell, S. D. 1987. Food chain dynamics: The central theory of ecology? Oikos 50:291-301.

Gaillard, J. M., M. Festa-Bianchet, and N. G. Yoccoz. 1998. Population dynamics of large herbivores: variable recruitment with constant adult survival. Trends in Ecology and Evolution 13:58-63.

Gasaway, W. C., R. O. Stephenson, J. L. Davis, P. E. K. Shepherd, and O. E. Burris. 1983. Interrelationships of wolves, prey, and man in interior Alaska. Wildlife Monographs $84: 1-50$.

Gese, E. M. 2001. Monitoring of terrestrial carnivore populations. Pages 372-396 in J. L. Gittleman, S. M. Funk, D. W. Macdonald, and R. K. Wayne, editors. Carnivore conservation. Cambridge University Press, London, UK.

Gese, E. M. 2004. Coyote in Yellowstone National Park: the influence of dominance on foraging, territoriality, and fitness. Pages 271-283 in D. W. Macdonald and C. Sillero-Zubiri, editors. Biology and conservation of wild canids. Oxford University Press, New York, New York, USA.

Gese, E. M., D. E. Andersen, and O. J. Rongstad. 1990. Determining home-range size of resident coyotes from point and sequential locations. Journal of Wildlife Management 54:501-505.

Gese, E. M., O. J. Rongstad, and W. R. Mytton. 1987. Manual and net-gun capture of coyotes from helicopters. Wildlife Society Bulletin 15:444-445.

Gittleman, J. L. 1985. Carnivore body size: ecological and taxonomic correlates. Oecologia 67:540-554. 
Gittleman, J. L., and M. E. Gompper. 2001. The risk of extinction: What you don't know will hurt you. Science 29: 997-999.

Gotelli, N. J., and A. M. Ellison. 2004. A primer of ecological statistics. Sinauer Associates, Sunderland, Massachusetts, USA.

Gregg, M. A., M. Bray, K. M. Kilbride, and M. R. Dunbar. 2001. Birth synchrony and survival of pronghorn fawns. Journal of Wildlife Management 65:19-24.

Hairston, N. G., F. E. Smith, and L. B. Slobodkin. 1960. Community structure, population control, and competition. American Naturalist 94:421-425.

Hebblewhite, M., C. A. White, C. G. Nietvelt, J. A. McKenzie, T. E. Hurd, J. M. Fryxell, S. E. Bayley, and P. C. Paquet. 2005. Human activity mediates a trophic cascade caused by wolves. Ecology 86:2135-2144.

Henke, S. E., and F. C. Bryant. 1999. Effects of coyote removal on the faunal community in western Texas. Journal of Wildlife Management 63:1066-1081.

Holling, C. S. 1965. The functional response of predators to prey density and its role in mimicry and population regulation. Memoirs of the Entomological Society of Canada 45:3-60.

Johnson, W. E., E. Eizirik, and G. M. Lento. 2001. The control, exploitation, and conservation of carnivores. Pages 196-219 in J. L. Gittleman, S. M. Funk, D. Macdonald, and R. K. Wayne, editors. Carnivore conservation. Cambridge University Press, Cambridge, UK.

Krefting, L. W. 1969. The rise and fall of the coyote on Isle Royale. Naturalist 20:24-31.

McLaren, B. E., and R. O. Peterson. 1994. Wolves, moose, and tree rings on Isle Royale. Science 266:1555-1558.

Micheli, F., G. A. Polis, P. D. Boersma, M. A. Hixon, E. A. Norse, P. V. R. Snelgrove, and M. E. Soulé. 2001. Human alteration of food webs: research priorities for conservation and management. Pages 31-57 in M. E. Soulé and G. H. Orians, editors. Conservation biology: research priorities for the next decade. Island Press, Washington, D.C., USA.

Ogada, M. O., R. Woodroffe, N. O. Oguge, and L. G. Frank. 2003. Limiting depredation by African carnivores: the role of livestock husbandry. Conservation Biology 17:1521-1530.

Oksanen, L., S. D. Fretwell, J. Arruda, and P. Niemela. 1981. Exploitation ecosystems in gradients of primary productivity. American Naturalist 118:240-261.

Paine, R. T. 1980. Food webs: linkage, interaction strength, and community infrastructure. Journal of Animal Ecology 49: 667-685.

Paquet, P. C. 1992. Prey use strategies of sympatric wolves and coyotes in Riding Mountain National Park, Manitoba. Journal of Mammalogy 73:337-343.

Peterson, R. O. 1995a. Wolves as interspecific competitors in canid ecology. Pages 315-324 in L. N. Carbyn, S. H. Fritts, and D. R. Seip, editors. Ecology and conservation of wolves. Circumpolar Press, Edmonton, Alberta, Canada.

Peterson, R. O. 1995b. The wolves of Isle Royale. Willow Press Creek, Minocqua, Wisconsin, USA.

Polis, G. A. 1999. Why are parts of the world green? Multiple factors control productivity and the distribution of biomass. Oikos 86:3-15.

Polis, G. A., and R. D. Holt. 1992. Intraguild predation: the dynamics of complex trophic interactions. Trends in Ecology and Evolution 7:151-153.

Polis, G. A., A. L. Sears, G. R. Huxel, D. R. Strong, and J. Maron. 2000. When is a trophic cascade a trophic cascade? Trends in Ecology and Evolution 15:473-475.
R Development Core Team. 2006. R: A language and environment for statistical computing. R Foundation for Statistical Computing, Vienna, Austria.

Ray, J. C., K. H. Redford, J. Berger, and R. Steneck. 2005. Is large carnivore conservation equivalent to biodiversity conservation and how can we achieve both? Pages 400-427 in J. C. Ray, K. H. Redford, R. S. Steneck, and J. Berger, editors. Large carnivores and the conservation of biodiversity. Island Press, Washington, D.C., USA.

Ripple, W. J., E. J. Larsen, R. A. Renkin, and D. W. Smith. 2001. Trophic cascades among wolves, elk and aspen on Yellowstone National Park's northern range. Biological Conservation 102:227-234.

Rogers, C. M., and M. J. Caro. 1998. Song sparrows, top carnivores and nest predation: a test of the mesopredator release hypothesis. Oecologia 116:227-233.

Schaller, G. B. 1996. Carnivores and conservation biology. Pages 1-10 in J. L. Gittleman, editor. Carnivore behavior, ecology, and evolution. Cornell University Press, Ithaca, New York, USA.

Sinclair, A. R. E. 1995. Population limitation of resident herbivores. Pages 194-219 in A. R. E. Sinclair and P. Arcese, editors. Serengeti II: dynamics, management and conservation of an ecosystem. University of Chicago Press, Chicago, Illinois, USA.

Smith, B. L. 1991. Jackson Hole elk. Bugle, Fall 1991:2-15.

Smith, B. L., E. K. Cole, and D. S. Dobkin. 2004. Imperfect pasture: a century of change at the National Elk Refuge in Jackson Hole, Wyoming. U.S. Fish and Wildlife Service, Jackson, Wyoming, USA.

Smith, D. W., R. O. Peterson, and D. B. Houston. 2003. Yellowstone after wolves. Bioscience 53:331-340.

Soulé, M. E., D. T. Bolger, A. C. Alberts, J. Wrights, M. Sorice, and S. Hill. 1988. Reconstructed dynamics of rapid extinctions of chaparral-requiring birds in urban habitat islands. Conservation Biology 2:75-92.

Steneck, R. S. 2005. An ecological context for the role of large carnivores in conserving biodiversity. Pages 9-33 in J. C. Ray, K. H. Redford, R. S. Steneck, and J. Berger, editors. Large carnivores and the conservation of biodiversity. Island Press, Washington, D.C., USA.

Switalski, T. S. 2003. Coyote foraging ecology and vigilance in response to gray wolf reintroduction in Yellowstone National Park. Canadian Journal of Zoology 81:985-993.

Terborgh, J., L. Lopez, P. Nuñez, M. Rao, G. Shahabuddin, G. Orihuela, M. Riveros, R. Ascanio, G. H. Adler, T. D. Lambert, and L. Balbas. 2001. Ecological meltdown in predator-free forest fragments. Science 294:1923-1926.

Weber, W., and A. Rabinowitz. 1996. A global perspective on large carnivore conservation. Conservation Biology 10:10461054 .

White, G. C., and K. P. Burnham. 1999. Program MARK: survival estimation from populations of marked animals. Bird Study 46(Supplement):120-138.

White, G. C., and R. A. Garrott. 1990. Analysis of wildlife radio-tracking data. Academic Press, London, UK.

Woodroffe, R. 2001. Strategies for carnivore conservation: lessons learned from contemporary extinctions. Pages 61-92 in J. L. Gittleman, S. M. Funk, D. Macdonald, and R. K. Wayne, editors. Carnivore conservation. Cambridge University Press, Cambridge, UK.

Woodroffe, R., and J. R. Ginsberg. 1998. Edge effects and the extinction of populations inside protected areas. Science 280: 2126-2128.

Worton, B. J. 1989. Kernel methods for estimating the utilization distribution in home-range studies. Ecology 70 : 164-168. 